\title{
Sublingual Traumatic Ulcerative Lesions Caused by the Eruption of First Primary Mandibular Molars: a Case Report
}

\author{
Lesión Ulcerativa Traumática Sublingual Causada por la Erupción del Primer Molar Temporal: \\ Reporte de un Caso
}

*Cassia Cilene Dezan; * Luiz Reynaldo de Figueiredo Walter; ${ }^{* * *}$ Karin Weber-Gasparoni;
******aão Paulo Menck Sangiorgio; ${ }^{* * * * *}$ Bruna Nogari \& ${ }^{* * * * * *}$ Karen Barros Parron Fernandes

DEZAN, C. C.; WALTER, F. L. R.; WEBER-GASPARONI, K.; SANGIORGIO,M. J. P.; NOGARI, B. \& FERNANDES P, K. B. Sublingual traumatic ulcerative lesions caused by the eruption of first primary mandibular molars: a case report. Int. J. Morphol., 29(4):1136-1138, 2011.

SUMMARY: Traumatic ulceration of the ventral surface of the tongue is an uncommon condition in infants and toddlers, which is often associated with natal and neonatal teeth in newborns. The aim of this report is to present a case of bilateral ulcerative ulcers on the ventral surface of the tongue caused by the eruption of first primary mandibular molars in a 14-month-old male child. The child was able to point to the lesions and also refused to consume certain beverages and foods, which favored an early diagnosis. Clinical treatment consisted of manual smoothing of the sharp edges of both mandibular first molars and a home regimen of lidocaine hydrochloride solution (Xylocaine ${ }^{\circledR}$, Astra) and a steroid solution of triamcinolone acetonide (Omcilon - A, Brystol-Myers) for symptoms relief and lesion healing, respectively. Complete healing of both lesions and normal feeding were both observed at a one-week follow-up exam. Early detection of the lesions and parental compliance with recommended home regimens were key factors for a successful treatment outcome, since untreated cases of tongue ulcerative lesions may evoke feeding difficulties and failure to thrive. Although there are several reports of ulcerative lesions on the tongue caused by dental eruption, they are usually associated with the eruption of mandibular primary incisors (Riga-Fede disease). However, there are no reports of ulcerative lesions caused by other primary teeth.

KEY WORDS: Tongue; Ulcerative lesion; Dental eruption; Riga-Fede disease; Primary teeth.

\section{INTRODUCTION}

Traumatic ulceration of the ventral surface of the tongue is an uncommon condition in infants and toddlers, with Riga-Fede disease being the most documented. Although rare and benign, the lesion begins as an ulcerated area and, with repeated trauma, it may progress to an enlarged, fibrous mass with the appearance of an ulcerative granuloma (Hegde, 2005). It is often associated with the presence of natal or neonatal teeth in newborns, resulting in pain during bottle- or breastfeeding, as well as nutritional concerns for the child (Baghdadi, 2001; Buchanan \& Jenkins, 1997; Goho, 1996; Slayton, 2000; Uzamis, et al., 1999). An association of Riga-Fede disease with neurological diseases, such as familial dysautonomia (Riley-Day syndrome, characterized by indifference to pain) and developmental delay (i.e. Down syndrome) has been reported (Baghdadi, 2001). Moreover, microcephaly associated with Riga-Fede disease in a 12month-old female was also reported (Baghdadi, 2002).

Riga-Fede was described clinically by Riga in 1881 and histologically by Fede in 1890 (Riga, 1888; Fede, 1890). Common treatments for Riga-Fede disease described in the literature include smoothing off cusps and incisal edges of teeth, tooth extraction, the use of tongue protectors, composite resin over tooth edges, modification on dietary habits and feeding devices, as well as palliative treatment of symptoms (Goho; Hegde; Slayton; Uzamis, et al.).

DDS, MS, PhD, Department of Pediatric Dentistry, School of Dentistry, State University of Londrina, Brazil.

** DDS, PhDSchool of Dentistry, State University of Londrina, Brazil.

*** DDS, MS, PhD, School of Dentistry, University of Iowa, USA.

***** DDSSchool of Dentistry, State University of Londrina, Brazil.

****** Graduate student, Biological and Health Sciences Center, University of Northern Parana, Brazil.

******* DDS, MS, PhD Department of Pharmacology, School of Dentistry, University of Northern Parana, Brazil. 
The purpose of this case report is to describe a unique case of bilateral ulcers on the ventral surface of the tongue of a 14-month-old healthy child caused by dental trauma associated with the eruption of first primary mandibular molars.

\section{CASE REPORT}

A healthy 14 month-old Caucasian male was seen at Bebê-Clínica (Baby Clinic) at the Universidade Estadual de Londrina - Brazil because of two bilateral ulcers on the ventral surface of his tongue. According to his mother, both ulcers were noticed about one week prior to dental appointment, period that coincided with the eruption of the child's first primary mandibular molars. In addition, the mother also reported that the child had difficulties with feeding in the past week, especially with citric foods and beverages such as tomato and orange juice. Clinical examination revealed bilateral ulcers on the ventral surface of the child's tongue in the area adjacent to the first primary mandibular molars. The lesion observed in the right side was approximately $1.5 \mathrm{~cm}$ in height and $1 \mathrm{~cm}$ in width (Fig. 1), while the lesion in the left side was $1 \mathrm{~cm}$ and $0.5 \mathrm{~cm}$ respectively (Fig. 2). Sharp cuspids in both first primary mandibular molars were also noted during the clinical exam.

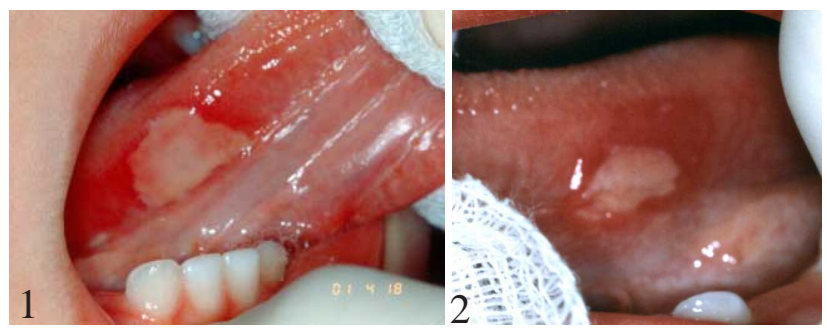

Fig. 1. Ulcerative tongue lesion observed on the right side on the ventral surface of the tongue.

Fig. 2. Ulcerative tongue lesion observed on the left side on the ventral surface of the tongue.

The treatment protocol, possible discomfort or risks, as well as benefits of the treatment were fully explained to the child's parents and a written informed consent was obtained prior to clinical treatment.

The treatment approach focused on removing the irritation source of the ventral surface of the patient's tongue and relief of the symptoms associated with both ulcerative lesions. Manual smoothing of the cuspids of both first primary mandibular molars using a sandpaper disk (tied with a dental floss to facilitate its recovery if accidentally lost in the child's mouth) was performed after application of a topical anesthetic solution of lidocaine hydrochloride (Xylocaine ${ }^{\circledR}$, Astra) on both lesions. In order to avoid unintentional injuries caused by sharp rotating instruments in an uncooperative wiggling young dental patient, manual smoothing using a sandpaper disk was preferable over the use of a hand-piece instrument. For the dental smoothing of the cuspids on both molars, the child was placed on an equipment device especially designed for treatment of young pediatric patients called "Macri". The mother was present to help in restraining the child's hands. She was advised to apply the same topical anesthetic solution (Xylocaine ${ }^{\circledR}$, Astra) prior to meals to alleviate the symptoms of discomfort and assure that the child would be able to eat properly, and a topical steroid anti-inflammatory in oralbase ointment (Omcilon-A, Brystol-Myers) three times a day for a period of one week to favor a faster healing of both ulcers. At oneweek follow-up exam, the mother reported that the child was eating properly and a complete healing of both lesions on the ventral surface of his tongue was observed.

\section{DISCUSSION}

This paper describes a unique case of bilateral ulcers on the ventral surface of the tongue associated with dental trauma caused by the eruption of first primary mandibular molars. There are several reports of ulcerative lesions on the ventral surface of the tongue caused by dental eruption, usually associated to primary lower incisors eruption which is classically described as Riga-Fede disease (Buchanan \& Jenkins; Goho; Hegde; Uzamis s et al.).

However, there are no reports of ulcerative lesions caused by other primary teeth. On the other hand, the similarities of the clinical findings of both bilateral lesions described in this case report match the ones reported in cases of Riga-Fede disease (Buchanan \& Jenkins; Goho; Hegde; Slayton; Uzamis, et al.). It is very likely that repeated trauma of the ventral surface of the tongue against the newly erupted first primary mandibular molars not only predispose these lesions, but also allow them to progress to enlarged lesions. The child was able to point the lesions and also refused to consume some beverages and foods, favoring their prompt diagnosis.

This uncommon location of both ulcers on the ventral surface of the patient's tongue could be explained mainly by two factors. First, the eruption of these teeth initiates the establishment of the posterior occlusion and, consequently, it forces the tongue to be positioned within the oral cavity itself, lingually to the mandibular teeth, and not anymore 
between both maxillary and mandibular arches (Walter $e t$ al., 2000). Both ulcers described in this case report appeared during this transitional stage of the tongue, period in which the patient's first primary mandibular molars were still erupting. Second, both first mandibular molars presented more sharpened cuspids than usually seen, which favored the onset of the traumatic lesions of the ventral surfaces of his tongue.
Untreated cases of tongue ulcerative lesions caused by dental eruption constitute a major concern for the health of a young child due to the risk of dehydration, feeding difficulties and failure to thrive because of the pain normally associated with this condition (Buchanan \& Jenkins; Goho; Hegde). In this case report, early detection of the lesions and parental compliance with recommended home regimens were key factors for a successful treatment outcome.

DEZAN, C. C.; WALTER, F. L. R.; WEBER-GASPARONI, K.; SANGIORGIO,M. J. P.; NOGARI, B. \& FERNANDES P, K. B. Lesión ulcerativa traumática sublingual causada por la erupción del primer molar temporal: reporte de un caso. Int. J. Morphol., 29(4):11361138, 2011.

RESUMEN: La ulceración traumática de la superficie ventral de la lengua es una condición poco común en bebés y niños pequeños, la cual se asocia a menudo con los dientes natales y neonatales en los recién nacidos. El objetivo de este reporte es presentar un caso de úlceras bilaterales en la superficie ventral de la lengua causada por la erupción de los primeros molares mandibulares temporales en un infante de sexo masculino de 14 meses de edad. En niño fue capaz de señalar las lesiones y se negó a consumir ciertas bebidas y alimentos, lo que favoreció un diagnóstico precoz. El tratamiento clínico consistió en el suavizado manual de los bordes afilados de los primeros molares inferiores y un régimen casero de solución de clorhidrato de lidocaína (Xilocaína®, Astra) junto a la solución esteroidal de acetónido de triamcinolona (Omcilon - A, Brystol-Myers) para el alivio de los síntomas y curación de la lesión respectivamente. La curación completa de ambas lesiones y la alimentación normal se observó en una semana del control de seguimiento. La detección temprana de las lesiones y el cumplimiento de los padres con los regímenes caseros recomendados, son factores claves para un resultado exitoso del tratamiento, ya que los casos no tratados de estas lesiones ulcerosas pueden provocar dificultades en la alimentación y una evolución inadecuada. Aunque existen varios informes de lesiones ulcerosas en la lengua causada por la erupción dental, que se asocian generalmente con la erupción de los incisivos mandibulares temporales (enfermedad de Riga-Fede). Sin embargo, no existen informes de lesiones ulcerosas causadas por otros dientes temporales.

PALABRAS CLAVE: Lengua; Lesión ulcerativa; Erupción dental; Enfermedad de Riga-Fede; Diente temporal.

\section{REFERENCES}

Baghdadi, Z. D. Riga-Fede disease: report of a case and review. $J$. Clin. Pediatr. Dent., 25(3):209-13, 2001.

Baghdadi, Z. D. Riga-Fede disease: association with microcephaly. Int. J. Paediatr. Dent., 12(6):442-5, 2002.

Buchanan, S. \& Jenkins, C. R. Riga-Fedes syndrome: natal or neonatal teeth associated with tongue ulceration. Case report. Aust. Dent. J., 42(4):225-7, 1997.

Fede, F. Della produzione sottolinguale o malattia di Riga. Atto Congresso Italiano di Pediatria, Napoli, 1890.

Goho, C. Neonatal sublingual traumatic ulceration (Riga-Fede disease): reports of cases. ASDC J. Dent. Child., 63(5):362-4, 1996.

Hegde, R. J. Sublingual traumatic ulceration due to neonatal teeth (Riga-Fede disease). J. Indian Soc. Pedod. Prev. Dent., 23(1):51-2, 2005.

Riga, A. Di una malattia della prima infanzia, Probabilmente non trattata, di movimenti patologici. Napoli, 1881.
Slayton, R. L. Treatment alternatives for sublingual traumatic ulceration (Riga-Fede disease). Pediatr. Dent., 22(5):413-4, 2000 .

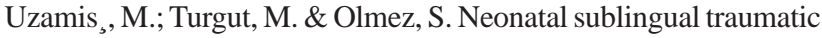
ulceration (Riga-Fede disease): a case report. Turk. J. Pediatr., 41(1):113-6, 1999.

Walter, L. R. F.; Ferelle, A. \& Issao, M. Análisis y desarrollo de la dentition decidua. In: Odontología para el bebé. Caracas, Actualidad de Médico Odontológicas Latino América, 2000. pp.34-43

Correspondence to:

Cássia Cilene Dezan, DDS, MS, PhD

Department of Oral Medicine and Dentistry for Children

Rua Pernambuco, 520

Centro

CEP: $86020-120$

Londrina-PR

BRASIL

Ema:dgcassia@gmail.com
Received: 17-12-2010

Accepted: 25-01-2011 